\title{
Appearance of glucose-induced insulin release in fetal rat $\beta$-cells
}

\author{
P Bergsten, K Aoyagi ${ }^{1}$, E Persson, U J Eriksson and C Hellerström \\ Department of Medical Cell Biology, Uppsala University, Box 571, S-751 23 Uppsala, Sweden and 'Third Department of Internal Medicine, Hirosaki University, \\ Aomori, Hirosaki, Japan \\ (Requests for offprints should be addressed to P Bergsten)
}

\begin{abstract}
Fetal rat pancreatic cells were isolated from pancreatic primordia on days $12-14$ of pregnancy and cultured for $48 \mathrm{~h}$ in the presence of $5 \mathrm{mmol} / 1$ glucose. Insulin accumulation in the medium over the next $24 \mathrm{~h}$ was measured. Cultured cells from day 12 fetuses secreted about $1 \mathrm{fmol}$ insulin per pancreas in response to 5 or $15 \mathrm{mmol} / 1$ glucose irrespective of whether $1 \mathrm{mmol} / 1$ tolbutamide, $400 \mu \mathrm{mol} / \mathrm{l}$ diazoxide, $5 \mathrm{mmol} / \mathrm{l}$ theophylline or $10 \mathrm{mmol} / 1$ mannoheptulose was present. In contrast, insulin released from day 13 cultured cells increased significantly from $3 \cdot 0 \pm 0.6$ to $6 \cdot 2 \pm 2 \cdot 2 \mathrm{fmol}$ per pancreas, when the glucose concentration was raised. Tolbutamide increased, diazoxide and mannoheptulose decreased and theophylline had no effect on insulin release. Even more pronounced effects were found on insulin release from day 14 cultured cells, in which theophylline also increased the release. In addition, insulin
\end{abstract}

release from cells from pregnancy day 14 was $75 \pm 16$ $\mathrm{amol} / \mathrm{min}$ per pancreas when the cells were perifused for 15-20 $\mathrm{min}$ in the presence of $5 \mathrm{mmol} / 1$ glucose within $3 \mathrm{~h}$ of isolation. Increasing the glucose concentration to $15 \mathrm{mmol} / 1$ or adding tolbutamide increased, whereas diazoxide decreased, insulin release in the freshly isolated cells. The insulin content of rat pancreata from pregnancy day 13 was $0.06 \pm 0.01$ pmol per pancreas and increased approximately 10 -fold every second day up to $6 \cdot 7 \pm 0.9$ pmol on day 17 of pregnancy. Between day 17 and 19 the pancreatic insulin content increased about fivefold to $39 \pm 2 \mathrm{pmol}$. The present data suggest that critical components of the insulin-secretory machinery, including ATP-regulated $\mathrm{K}^{+}$channels, glucokinase and adenylate cyclase activities, are present in the developing $\beta$-cell earlier than hitherto thought.

Journal of Endocrinology (1998) 158, 115-120

\section{Introduction}

In adult life the plasma insulin response to an abrupt increase in blood glucose concentration is characterized by a biphasic pattern. However, this characteristic pattern does not manifest itself until after birth, and a low and sluggish response to glucose has been reported on days 19.5-20 of pregnancy in the rat (Asplund et al. 1969, Asplund 1973, Sodoyez-Goffaux et al. 1979, Rhoten 1980, Grill et al. 1981, Freinkel et al. 1984, Hole et al. 1988, Hughes 1994, Bliss \& Sharp 1994). Recently we demonstrated that rat $\beta$-cells cultured for 3 days are already responsive to glucose when explanted on day 16 of pregnancy (Aoyagi et al. 1997). Furthermore, rat pancreatic $\beta$-cells can be identified on pregnancy day 12 (Rall et al. 1973, Yoshinari \& Daikoku 1982). The regulation of fetal insulin release at this early stage of $\beta$-cell development has not been studied previously, largely because of insufficient sensitivity of the insulin assays. With the aid of a very sensitive insulin assay (Bergsten \& Hellman 1993) and our newly developed technique for maintenance of early fetal pancreatic cells in culture (Aoyagi et al. 1997), we have now been able to measure the insulin-secretory response to glucose of rat fetal $\beta$-cells explanted as early as day 12 of pregnancy and cultured for 3 days. To confirm that the glucose sensitivity was not induced by the tissue culture, freshly isolated rat fetal $\beta$-cells from pregnancy day 14 were studied with respect to glucose-stimulated insulin release. We also investigated to what extent this early secretory response of the fetal rat $\beta$-cells is affected by two non-glucose modulators of the ATP-sensitive $\mathrm{K}^{+}$channel, namely tolbutamide and diazoxide, by the phosphodiesterase inhibitor theophylline and by the glucokinase inhibitor mannoheptulose. Accumulation of insulin in the fetal rat pancreas was followed from day 13 to day 19 of pregnancy.

\section{Materials and Methods}

\section{Chemicals}

RPMI 1640 culture medium without glucose, Hanks balanced salts solution (with and without calcium and magnesium), penicillin and streptomycin solution, $0.5 \%$ trypsin (containing 0.2\% EDTA) solution, 0.5\% trypan blue solution and fetal calf serum were supplied by 
HyClone (Cramlington, Northumberland, UK); BSA was from Miles (Slough, Bucks, UK); D-glucose, D-mannoheptulose, Hepes, tetramethylbenzidine, theophylline and insulin-peroxidase came from Sigma Chemicals (St Louis, MO, USA); ${ }^{125}$ I-labeled insulin was from Euro-Diagnostica AB (Malmö, Sweden); guinea-pig insulin antibody for the RIA was purchased from MilesYeda (Rehovot, Israel); insulin standard was obtained from Novo Nordisk (Bagsvaerd, Denmark); IgG-certified microtiter plates came from Nunc (Roskilde, Denmark). The mouse insulin antibodies used in the ELISA were raised in our laboratory from guinea-pigs. Diazoxide was a gift from Schering Corp. (Kenilworth, NJ, USA) and tolbutamide from Hoechst AG (Frankfurt/Main, Germany).

\section{Animals and preparation of pancreatic cells}

Sprague-Dawley rats bred at our department were used. The rats were fed a commercial pelleted diet $(\mathrm{AB}$ Analysen, Lidköping, Sweden) and had free access to food and tap water. They were maintained at an ambient temperature of $22{ }^{\circ} \mathrm{C}$ with a $12 \mathrm{~h}$ light $/ 12 \mathrm{~h}$ darkness cycle. Female and male rats were caged together during the night. The appearance of spermatozoa in the vaginal smear on the following morning defined day 0 of gestation. Isolation and culture of fetal pancreatic cells were performed as recently described (Aoyagi et al. 1997). Briefly, pancreata were dissected from fetuses on pregnancy days 12-14. In 12-13-day-old fetuses, pancreatic buds were dissected together with adjacent gut and surrounding mesenchyme. After trypsinization the dispersed cells were washed, counted and viability of the cells determined by trypan blue exclusion.

\section{Culture of fetal pancreatic cells}

Pancreatic cells from fetuses removed on pregnancy days 12-14 were resuspended in culture medium containing $5 \mathrm{mmol} / \mathrm{l}$ glucose and plated in 24-well tissue culture plates (Multiwell; Falcon, Lincoln Park, NJ, USA). Cells from fetuses of the same day of pregnancy were pooled, and the average number added to each well was 75000 (day 12), 94000 (day 13) and 100000 (day 14). After an initial $48 \mathrm{~h}$ culture period, new medium $(500 \mu \mathrm{l})$ was added containing $5 \mathrm{mmol} / \mathrm{l}$ glucose in the presence or absence of $1 \mathrm{mmol} / 1$ tolbutamide or $15 \mathrm{mmol} / 1$ glucose in the presence or absence of $5 \mathrm{mmol} / \mathrm{l}$ theophylline, $400 \mu \mathrm{mol} / \mathrm{l}$ diazoxide or $10 \mathrm{mmol} / 1 \mathrm{mannoheptulose}$ and incubation continued for an additional $24 \mathrm{~h}$ period.

\section{Perifusion of freshly isolated fetal pancreatic cells}

Pancreatic cells from fetuses removed on pregnancy day 14 were resuspended in medium containing (mmol/l) 125 $\mathrm{NaCl}, 5.9 \mathrm{KCl}, 1 \cdot 2 \mathrm{MgCl}_{2}, 1 \cdot 28 \mathrm{CaCl}_{2}, 25$ Hepes,
5 glucose and $0.5 \mathrm{mg} / \mathrm{ml} \mathrm{BSA}$, titrated to $\mathrm{pH} 7 \cdot 4$ with $\mathrm{NaOH}$. The cells were allowed to attach to a glass coverslip used as the bottom of an open chamber (Sykes \& Moore 1959). The number of cells added to the coverslips was $186000 \pm 29000$. To ensure attachment of the cells, the coverslips were coated with poly-L-lysine, and an incubation period of $2 \mathrm{~h}$ preceded the subsequent perifusion of the cells with the same medium. After $60 \mathrm{~min}$ of perifusion, sampling of the perifusate for insulin determination began before the glucose concentration was raised from 5 to $15 \mathrm{mmol} / \mathrm{l}$. Before sampling in the presence of $1 \mathrm{mmol} / \mathrm{l}$ tolbutamide and $5 \mathrm{mmol} / \mathrm{l}$ glucose, the cells were perifused in the presence of $5 \mathrm{mmol} / \mathrm{l}$ glucose for $15 \mathrm{~min}$. Similarly, the cells were perifused in the presence of $15 \mathrm{mmol} / \mathrm{l}$ glucose alone before sampling in the presence of $400 \mu \mathrm{mol} / 1$ diazoxide and $15 \mathrm{mmol} / 1$ glucose. The sampling period was $10-20 \mathrm{~min}$ for each condition.

\section{Measurements of insulin release and accumulation and of pancreatic insulin content}

Insulin release in the perifusate and accumulation in aliquots of the culture medium taken after the $24 \mathrm{~h}$ culture period was measured with a competitive ELISA with the insulin-capturing antibody immobilized directly in the solid phase essentially as described previously (Bergsten \& Hellman 1993). Amounts of insulin were calculated from linear standard curves in semilogarithmic plots with a detection limit of 100 amol. Rates of insulin release or insulin accumulation were expressed as amol insulin secreted $/ \mathrm{min}$ per pancreas or fmol insulin $/ 24 \mathrm{~h}$ per pancreas for the perifused and cultured cells respectively. For determination of insulin content in fetal pancreata of pregnancy days 13-19, the dissected tissue was placed in acid alcohol $(0.18 \mathrm{~mol} / 1 \mathrm{HCl}$ in $70 \%(\mathrm{v} / \mathrm{v})$ ethanol), disrupted ultrasonically for extraction of insulin overnight at $4{ }^{\circ} \mathrm{C}$, centrifuged and stored at $-20{ }^{\circ} \mathrm{C}$. Insulin content was determined by RIA (Heding 1972) and expressed as pmol insulin per pancreas.

\section{Data computation and statistical analysis}

Data are expressed as mean \pm s.E.M. Each individual observation represents a separate experiment. Probabilities $(P)$ of chance differences between the experimental groups were calculated by the two-tailed Student's $t$-test for paired observations.

\section{Results}

Number of fetal pancreatic cells

Dispersed cells used for perifusion or monolayer culture were prepared from pancreata obtained from rat fetuses on 
Table 1 Insulin accumulation in the culture medium of dispersed fetal rat pancreactic cells from pregnancy days 12,13 and 14 over $24 \mathrm{~h}$ in the presence of 5 or $15 \mathrm{mmol} / \mathrm{l}$ glucose. Results are means \pm S.E.M. from four (day 12), eight (day 13) and ten (day 14) separate experiments

\begin{tabular}{|c|c|c|c|c|}
\hline \multirow[b]{3}{*}{$\begin{array}{l}\text { Glucose } \\
(\mathrm{mmol} / \mathrm{l})\end{array}$} & \multirow[b]{2}{*}{ Addition } & \multicolumn{3}{|c|}{$\begin{array}{l}\text { Insulin release } \\
\text { (fmol/24 h per pancreas) }\end{array}$} \\
\hline & & 12 & 13 & 14 \\
\hline & & & & \\
\hline 5 & - & $1 \cdot 0 \pm 0 \cdot 6$ & $3 \cdot 0 \pm 0 \cdot 6$ & $6 \cdot 9 \pm 1 \cdot 3$ \\
\hline 15 & - & $1 \cdot 0 \pm 0 \cdot 2$ & $6 \cdot 2 \pm 2 \cdot 2^{\mathrm{a}}$ & $17 \cdot 2 \pm 3 \cdot 1^{b}$ \\
\hline 5 & Tolbutamide & $1 \cdot 2 \pm 0 \cdot 6$ & $6 \cdot 4 \pm 1 \cdot 6^{c}$ & $13 \cdot 5 \pm 2 \cdot 8^{\mathrm{c}}$ \\
\hline 15 & Diazoxide & $0.9 \pm 0 \cdot 2$ & $4 \cdot 0 \pm 1 \cdot 5^{\mathrm{c}}$ & $6 \cdot 5 \pm 1 \cdot 6^{d}$ \\
\hline 15 & Theophylline & $1 \cdot 0 \pm 0 \cdot 2$ & $7 \cdot 1 \pm 2 \cdot 6$ & $45 \cdot 1 \pm 8 \cdot 6^{d}$ \\
\hline 15 & Mannoheptulose & $0 \cdot 6 \pm 0 \cdot 2$ & $3 \cdot 0 \pm 0 \cdot 6^{c}$ & $7 \cdot 2 \pm 1 \cdot 4^{\mathrm{d}}$ \\
\hline
\end{tabular}

Tolbutamide $(1 \mathrm{mmol} / \mathrm{l})$, diazoxide $(400 \mu \mathrm{mol} / \mathrm{l})$, theophylline $(5 \mathrm{mmol} / \mathrm{l})$, or mannoheptulose $(10 \mathrm{mmo} / \mathrm{l})$ were added as indicated. The cells were initially cultured for 2 days in a medium containing $5 \mathrm{mmol} / \mathrm{l}$ glucose. Statistical comparisons were performed by the two-tailed Student's $t$-test for paired observations. ${ }^{a} P<0.05$ and ${ }^{b} P<0.01$ denote the effect of increasing the glucose concentration. ${ }^{c} P<0.05$ and ${ }^{\mathrm{d}} \mathrm{P}<0.01$ denote the effect of the additions.

pregnancy days 12-14. The number of fetuses used were 31 (day 12), 43 (day 13) and 45 (day 14) for four, eight and ten separate experiments respectively. The total numbers of dispersed cells per fetus were $75300 \pm 2900$ (day 12), $96600 \pm 5600$ (day 13) and $149200 \pm 5500$ (day 14). More than $95 \%$ of the cells were viable after trypsinization as evidenced by trypan blue exclusion.

\section{Insulin release and accumulation}

Cultured pancreatic cells explanted on pregnancy day 12 and maintained in culture for 3 days accumulated about $1 \mathrm{fmol}$ insulin in the culture medium per pancreas during the preceding $24 \mathrm{~h}$ in the presence of $5 \mathrm{mmol} / 1$ glucose (Table 1). Neither an increase in glucose concentration to $15 \mathrm{mmol} / \mathrm{l}$, addition of $1 \mathrm{mmol} / \mathrm{l}$ tolbutamide in the presence of $5 \mathrm{mmol} / \mathrm{l}$ glucose or $400 \mu \mathrm{mol} / \mathrm{l}$ diazoxide in the presence of $15 \mathrm{mmol} / 1$ glucose, nor supplementation with $5 \mathrm{mmol} / 1$ theophylline or $10 \mathrm{mmol} / 1$ mannoheptulose in the presence of $15 \mathrm{mmol} / 1$ glucose during the last $24 \mathrm{~h}$ affected the rate of insulin accumulation. In contrast, during the last $24 \mathrm{~h}$ of culture, pancreatic cells explanted on pregnancy day 13 increased the insulin accumulation from $3 \cdot 0 \pm 0 \cdot 6$ to $6 \cdot 2 \pm 2 \cdot 2$ fmol per pancreas in response to a rise in the glucose concentration from 5 to $15 \mathrm{mmol} / \mathrm{l}$. Tolbutamide stimulated insulin accumulation in the presence of $5 \mathrm{mmol} / \mathrm{l}$ glucose as effectively as $15 \mathrm{mmol} / \mathrm{l}$ glucose alone. Diazoxide inhibited insulin accumulation in the presence of $15 \mathrm{mmol} / 1$ glucose almost to the level observed in the presence of $5 \mathrm{mmol} / \mathrm{l}$ glucose. Whereas addition of theophylline to the medium containing $15 \mathrm{mmol} / \mathrm{l}$ glucose did not affect insulin accumulation, mannoheptulose inhibited the rate of accumulation in the presence of $15 \mathrm{mmol} / \mathrm{l}$ glucose to that recorded in the presence of $5 \mathrm{mmol} / \mathrm{l}$ glucose. When cultured cells explanted on pregnancy day 14 were used, increasing the glucose concentration from 5 to $15 \mathrm{mmol} / \mathrm{l}$ enhanced the insulin accumulation about 2.5 times during the last $24 \mathrm{~h}$ in culture. Tolbutamide stimulated and diazoxide strongly inhibited insulin accumulation. In contrast, with cells from day 13, theophylline more than doubled the insulin accumulation observed in the presence of $15 \mathrm{mmol} / 1$ glucose. Mannoheptulose inhibited the glucose-stimulated insulin accumulation.

When freshly isolated pancreatic cells from pregnancy day 14 were perifused at $5 \mathrm{mmol} / \mathrm{l}$ glucose, they released $75 \pm 16 \mathrm{amol}$ insulin/min per pancreas (Table 2). Increasing the glucose concentration to $15 \mathrm{mmol} / \mathrm{l}$ increased the

Table 2 Insulin release of freshly isolated fetal rat pancreatic cells from pregnancy day 14 . Results are means \pm S.E.M. from five separate experiments

\begin{tabular}{|c|c|c|}
\hline & Addition & $\begin{array}{l}\text { Insulin release } \\
\text { (fmol/24 } \mathrm{h} \text { per pancreas) }\end{array}$ \\
\hline \multicolumn{3}{|l|}{$\begin{array}{l}\text { Glucose } \\
(\mathrm{mmol} / \mathrm{l})\end{array}$} \\
\hline 5 & - & $75 \pm 16$ \\
\hline 15 & - & $113 \pm 19^{a}$ \\
\hline 5 & Tolbutamide & $93 \pm 18^{b}$ \\
\hline 15 & Diazoxide & $61 \pm 12^{b}$ \\
\hline
\end{tabular}

Dispersed cells were allowed to attach to the bottom of the perifusion chamber for $2 \mathrm{~h}$ in medium containing $5 \mathrm{mmol} / /$ glucose before they were perifused at the same glucose concentration for $60 \mathrm{~min}$. The perifusate in the presence of 5 and $15 \mathrm{mmol} / \mathrm{l}$ glucose was sampled for 15-20 min each. Before the cells were exposed to $1 \mathrm{mmol} / \mathrm{l}$ tolbutamide or $400 \mu \mathrm{mol} / \mathrm{l}$ diazoxide, they were perifused in the presence of 5 or $15 \mathrm{mmol} / \mathrm{l}$ glucose alone for 10-15 min. Statistical comparisons were performed by the two-tailed Student's $t$-test for paired observations. ${ }^{a} P<0.005$ denotes the effect of increasing the glucose concentration. ${ }^{b} P<0 \cdot 05$ denotes the effect of the additions. 
Table 3 Insulin content of freshly isolated fetal pancreatic glands from pregnancy days 13-19. Extracted insulin is given as mean \pm S.E.M. for the indicated number of experiments

\section{Insulin content} (pmol/pancreas)

\section{Day of pregnancy}

13

14

15

16

17

18

19
No. of

experiments

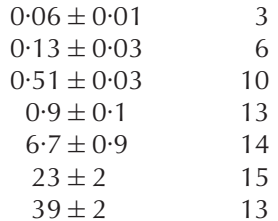

insulin release by $51 \%$. After the glucose concentration in the perifusion medium had been returned to $5 \mathrm{mmol} / \mathrm{l}$, $1 \mathrm{mmol} / 1$ tolbutamide caused a $24 \%$ increase in insulin release. In the presence of $15 \mathrm{mmol} / 1$ glucose, $400 \mu \mathrm{mol} / \mathrm{l}$ diazoxide decreased the rate of insulin release to $34 \%$ below that recorded in the presence of $5 \mathrm{mmol} / 1$ glucose.

\section{Insulin content}

The insulin content of freshly isolated fetal pancreatic glands from pregnancy day 13-19 is shown in Table 3. The hormonal content of day 13 pancreata, $0.06 \pm$ $0.01 \mathrm{pmol} /$ pancreas, increased approximately 10-fold every second day until pregnancy day 17 . There was a fivefold increase in the pancreatic insulin content between days 17 and 19.

\section{Discussion}

In the present study we show that rat pancreatic $\beta$-cells from the early fetal period respond to an increase in glucose concentration with release of insulin, although to a much smaller extent than adult cells. An inherent difficulty in the study of the early functional development of the fetal rat $\beta$-cell is the small size of the developing pancreas and the low proportion of insulin-containing cells, requiring a highly sensitive assay method for the measurement of the release and content of the hormone. By pooling pancreatic cells from fetuses of the same litter, it was possible to accumulate enough $\beta$-cells to obtain detectable amounts of insulin in response to different agents affecting the secretory rate of insulin. In the present study the tissue specimens obtained from the 12 to 13-day-old fetuses comprised not only the pancreatic primordia but also some of the surrounding mesenchymal and endodermal cells, which precluded meaningful calculations of insulin release on a per cell basis. However, care was taken to include the entire pancreatic primordium, which justifies the expression of both insulin release and content per individual pancreas. By the utilization of monolayer cultures of the fetal pancreatic cells (Aoyagi et al. 1997) and an insulin assay with a sensitivity of $100 \mathrm{amol}$ (Bergsten \& Hellman 1993), it became possible to assess the function of the developing $\beta$-cells.

The present experimental approach using a 3-day culture period of the pancreatic cells raises the question as to what extent the observed effects of the test substances reflected changes in the rates of differentiation and/or proliferation of $\beta$-cells rather than in the rates of insulin release from the individual $\beta$-cell. Assuming a cell cycle time of $15 \mathrm{~h}$ (Swenne 1992) for fetal rat $\beta$-cells, it is unlikely that proliferation of preformed $\beta$-cells in response to glucose could alone account for more than a fraction of the observed changes in insulin content of the culture medium. Accelerated neogenesis by differentiation of progenitor cells to $\beta$-cells is an alternative explanation, which cannot be entirely excluded. However, this would presuppose a rapid and marked induction of insulin gene transcription in a large number of progenitor cells affected by glucose, tolbutamide or theophylline with a very marked effect of the latter on pancreatic cells obtained on pregnancy day 14 . Although at later stages of development glucose is known to contribute to $\beta$-cell differentiation, there is little evidence of such an effect by either tolbutamide or theophylline (Swenne 1992). Nevertheless, it seemed important to confirm the occurrence of glucosestimulated insulin release in freshly prepared cells from the early fetal pancreas. Indeed, within a perifusion period of only $20 \mathrm{~min}$, the rate of insulin secretion from cells obtained after 14 days of gestation increased significantly in response to glucose. The finding that the release was increased by tolbutamide and decreased by diazoxide extended these observations to include a sensitivity also to sulfonylureas. Although these observations do not exclude the possibility that in the culture system differentiation and proliferation of $\beta$-cells may have contributed to insulin accumulation in the medium, they strongly support the view that the increased accumulation in the presence of high glucose reflected insulin release from glucosesensitive $\beta$-cells rather than changes in $\beta$-cell mass. It is nevertheless of note that the rate of insulin release at the basal glucose concentration $(5 \mathrm{mmol} / \mathrm{l})$ increased almost fivefold between pregnancy days 12 and 14. It is not clear if this was due to an increased $\beta$-cell mass alone or also to increased secretion by the individual $\beta$-cells.

It has been suggested that the immature insulin response of the fetal $\beta$-cell to glucose reflects the presence of a low level of the glucose transporter protein GLUT2 or a low activity of glucokinase (Hughes 1994, Tiedge \& Lenzen 1993). However, the latter proposal is challenged by the present results showing inhibition of insulin release by mannoheptulose and by a recent report in which fetal rat islets obtained on pregnancy day 21 showed amounts and activities of glucokinase similar to those found in adult islets ( $\mathrm{Tu} \&$ Tuch 1996). This indicates that glucokinase already has regulatory significance for insulin release in 
early $\beta$-cell development. However, there appears to be less glucose oxidation in the fetal than the adult $\beta$-cell (Rorsman et al. 1989). This could explain the lack of increase in the fetal islet ATP content after $30 \mathrm{~min}$ of exposure to high glucose levels (Rorsman et al. 1989, Wahl et al. 1992). The present observation of glucosesensitive insulin release already on day 14 of pregnancy nevertheless suggests a role for glucose metabolism in the regulation of fetal insulin release.

A stimulatory effect of glucose on insulin synthesis has been demonstrated in fresh fetal rat pancreas on pregnancy day 15 (Kakita et al. 1983) and in isolated islets from 20-day-old rat fetuses (Eriksson et al. 1980). However, in monolayer culture of pancreatic cells obtained on pregnancy day 16, glucose failed to stimulate insulin biosynthesis (Aoyagi et al. 1997), suggesting that the present glucose-induced increase in insulin release does not reflect an increase in insulin biosynthesis. Likewise it has been shown that theophylline has minimal effects on insulin biosynthesis in fetal $\beta$-cells of late gestation (Swenne 1982).

In the adult $\beta$-cell, the reduction in the permeability of the ATP-sensitive $\mathrm{K}^{+}$channel is an important step in membrane depolarization and opening of the voltage gated L-type $\mathrm{Ca}^{2+}$ channels, which leads to an increase in cytoplasmic $\mathrm{Ca}^{2+}$ concentration and insulin release (Hellman et al. 1988). Functional ATP-sensitive $\mathrm{K}^{+}$ channels, sensitive to sulfonylureas, and $\mathrm{Ca}^{2+}$ channels have been demonstrated in rat fetal $\beta$-cells from pregnancy day 16 (Weinhaus et al. 1995). Our results with glucose, tolbutamide and diazoxide indicate that the channels are already operational in $\beta$-cells explanted on pregnancy day 14. In these cells, tolbutamide in the presence of $5 \mathrm{mmol} / 1$ glucose induced an insulin release that was similar to or slightly lower than that produced in the presence of $15 \mathrm{mmol} / 1$ glucose. This suggests that the supply of ATP is the rate-limiting factor for insulin secretion, rather than depolarization of rat fetal $\beta$-cells, similar to the situation in adult pancreatic islets (Eliasson et al. 1997, Westerlund et al. 1997).

cAMP formation has been found to be lower in fetal than in adult rat $\beta$-cells (Grill et al. 1975), analogous to the lower ATP synthesis. When the low fetal cAMP levels were elevated in rat fetal $\beta$-cells of pregnancy day 21 by either inhibition of its breakdown or stimulation of its synthesis, glucose-induced insulin release was augmented (Ammon et al. 1989, Mourmeaux et al. 1989). The results of our study are well in line with these data and suggest that the potentiating effect of cAMP is effective well before day 21 of pregnancy.

The present results show for the first time that freshly isolated fetal rat $\beta$-cells from as early as gestational day 14 and cultured rat $\beta$-cells from as early as gestational day 13 secrete more insulin when the glucose concentration is increased. Until now the earliest dynamic measurements of insulin release from the fetal rat pancreas have been from days 19.5-20 of pregnancy and show a similar sustained and shallow response to glucose (Rhoten 1980, Bliss \& Sharp 1994). Furthermore, both the freshly isolated and the cultured glucose-responsive cells are also responsive to tolbutamide and diazoxide. Glucokinase activity seems to appear at the same stage, whereas theophyllinesensitivity, indicating increased adenylate cyclase activity, appears somewhat later. Our combined results indicate that critical components of the insulin-secretory machinery, such as ATP-sensitive $\mathrm{K}^{+}$channels, glucokinase and adenylate cyclase activities, are present in the developing $\beta$-cell earlier than hitherto known.

\section{Acknowledgements}

The authors are grateful to Else-Marie Andersson, Astrid Nordin, Margareta Engvist and Eva Törnelius for excellent technical assistance. The study was supported by the Swedish Medical Research Council (12X-109, 12X-7475, 12X-11203), the Swedish Diabetes Association, the Novo Nordisk Foundation and the Family Ernfors Foundation. The stay of K A in the Department of Medical Cell Biology was made possible by Professor Kazuo Takebe, Third Department of Internal Medicine, Hirosaki University, Aomori, Japan, the Medical Faculty of Uppsala University and the Swedish Diabetes Association.

\section{References}

Ammon HPT, Glockner C, Waldner RG \& Wahl MA 1989 Insulin release from pancreatic islets of fetal rats mediated by leucine b-BCH, tolbutamide, glibenclamide, arginine, potassium chloride, and theophylline does not require stimulation of $\mathrm{Ca}^{2+}$ net uptake. Cell Calcium 10 441-450.

Aoyagi K, Bergsten P, Eriksson UJ, Ebendal T \& Hellerström C 1997 In vitro regulation of insulin release and biosynthesis of fetal rat pancreatic cells explanted on pregnancy day 16. Biology of the Neonate 71 60-68.

Asplund K 1973 Dynamics of insulin release from the foetal and neonatal rat pancreas. European Journal of Clinical Investigation 3 338-344.

Asplund K, Westman S \& Hellerström C 1969 Glucose stimulation of insulin secretion from the isolated pancreas of foetal and newborn rats. Diabetologia 5 260-262.

Bergsten P \& Hellman B 1993 Glucose-induced amplitude regulation of pulsatile insulin secretion from individual pancreatic islets. Diabetes 42 670-674.

Bliss CR \& Sharp GWG 1994 Development of glucose responsiveness from the fetal to the adult B-cell. In Frontiers of Insulin Secretion and Pancreatic B-cell Research, pp 69-76. Eds PR Flatt \& S Lenzen. London: Smith-Gordon.

Eliasson L, Renström E, Ding WG, Proks P \& Rorsman P 1997 Rapid ATP-dependent priming of secretory granules precedes $\mathrm{Ca}^{2+}$-induced exocytosis in mouse pancreatic B-cells. Journal of Physiology 503 399-412.

Eriksson U, Andersson A, Efendic S \& Hellerström C 1980 Diabetes in pregnancy: effects on the fetal and newborn rat with particular regard to the body weight, serum insulin concentration and pancreatic contents of insulin, glucagon and somatostatin. Acta Endocrinologica 94 354-364. 
Freinkel N, Lewis NJ, Johnson RC, Swenne I, Bone A \& Hellerström C 1984 Differential effects of age versus glycemic stimulation on the maturation of insulin stimulus-secretion coupling during culture of fetal rat islets. Diabetes 33 1028-1038.

Grill V, Asplund K, Hellerström C \& Cerasi E 1975 Decreased cyclic AMP and insulin response to glucose in isolated islets of neonatal rats. Diabetes 24 746-752.

Grill V, Lake W \& Freinkel N 1981 Generalized diminution in the response to nutrients as insulin-releasing agents during the early neonatal period in the rat. Diabetes 30 56-63.

Heding LG 1972 Determination of total serum insulin (IRI) in insulin-treated patients. Diabetologia 8 260-266.

Hellman B, Gylfe E, Bergsten P, Johansson H \& Wesslén N 1988 Glucose-induced modifications of the calcium movements regulating insulin and glucagon release. In Pathogenesis of Non-Insulin Dependent Diabetes Mellitus, pp 39-60. Eds V Grill \& S Efendic. New York: Raven Press.

Hole RL, Pian-Smith MCM \& Sharp GWG 1988 Development of the biphasic response to glucose in fetal and neonatal rat pancreas. American Journal of Physiology 254 E167-E174.

Hughes SJ 1994 The role of reduced glucose transporter content and glucose metabolism in the immature secretory responses of fetal rat pancreatic islets. Diabetologia 37 134-140.

Kakita k, Gidding SJK, Rotwein PS \& Permutt MA 1983 Insulin gene expression in the developing rat pancreas. Diabetes $\mathbf{3 2}$ 691-696.

Mourmeaux JL, Remacle C \& Henquin JC 1989 Effects of stimulation of adenylate cyclase and protein kinase- $\mathrm{C}$ on cultured fetal rat B-cells. Endocrinology 125 2636-2644.

Rall LB, Pictet RL, Williams RH \& Rutter WJ 1973 Early differentiation of glucagon-producing cells in embryonic pancreas: a possible role for glucagon. Proceedings of the National Academy of Sciences of the USA $703478-3482$.

Rhoten WB 1980 Insulin secretory dynamics during development of rat pancreas. American Journal of Physiology 239 E57-E63.

Rorsman P, Arkhammar P, Bokvist K, Hellerström C, Nilsson T, Welsh M, Welsh N \& Berggren PO 1989 Failure of glucose to elicit a normal secretory response in fetal pancreatic beta cells results from glucose insensitivity of the ATP-regulated $\mathrm{K}^{+}$channels. Proceedings of the National Academy of Sciences of the USA $\mathbf{8 6}$ 4505-4509.

Sodoyez-Goffaux F, Sodoyez JC, De Vos CJ \& Fao PP 1979 Insulin and glucagon secretion by islets isolated from fetal and neonatal rats. Diabetologia 16 121-123.

Swenne I 1982 Effects of cyclic AMP on DNA replication and protein biosynthesis in fetal rat islets of Langerhans maintained in tissue culture. Bioscience Reports 2 867-876.

Swenne I 1992 Pancreatic beta-cell growth and diabetes mellitus. Diabetologia 35 193-201.

Sykes JA \& Moore EB 1959 A new chamber for tissue culture. Proceedings of the Society for Experimental Biology and Medicine 100 $125-127$.

Tiedge M \& Lenzen S 1993 Differential regulation of glucokinase and GLUT-2 glucose transporter gene expression in pancreas and liver from neonatal and 16 day old rats. Biochemical and Molecular Biology International 29 161-165.

Tu J \& Tuch BE 1996 Glucose regulates the maximal velocities of glucokinase and glucose utilization in the immature fetal rat pancreatic islet. Diabetes 45 1068-1075.

Wahl MA, Waldner RG \& Ammon HPT 1992 Potassium permeability of fetal rat pancreatic islets: abnormal sensitivity to glucose. Life Sciences 51 1631-1637.

Weinhaus AJ, Poronnik P, Cook DI \& Tuch BE 1995 Insulin secretagogues, but not glucose, stimulate an increase in $\left[\mathrm{Ca}^{2+}\right]_{\mathrm{i}}$ in the fetal rat $\beta$-cell. Diabetes 44 118-124.

Westerlund J, Gylfe G \& Bergsten P 1997 Pulsatile insulin release from pancreatic islets with nonoscillatory elevation of cytoplasmic $\mathrm{Ca}^{2+}$. Journal of Clinical Investigation 100 2547-2551.

Yoshinari M \& Daikoku S 1982 Ontogenetic appearance of immunoreactive endocrine cells in rat pancreatic islets. Anatomy and Embryology 165 63-70.

Received 21 July 1997

Revised manuscript received 8 December 1997

Accepted 19 February 1998 